\title{
TWO NEW SPECIES OF COUSSAREA AND A NEW COMBINATION IN FARAMEA (RUBIACEAE, COUSSAREEAE) FROM THE GUIANAS
}

\author{
PIERO G. DELPRETE \\ Nationaal Herbarium Nederland, Utrecht University branch, Heidelberglaan 2, \\ 3584 CS Utrecht, The Netherlands ${ }^{1}$
}

\section{SUMMARY}

During the preparation of the treatment of the family Rubiaceae for the Flora of the Guianas, two new species of Coussarea were discovered. One species, Coussarea longilaciniata, was collected in Guyana and is characterized by its long-lanceolate calyx lobes; the other, $C$. spicata, is from French Guiana and is unique in the genus by its spicate inflorescences. In addition, Faramea sessiliflora var. pedunculata is here elevated to the species level, and a new description of $F$. sessiliflora is also provided in view of the re-delimitation of this species.

Key words: Rubiaceae, Coussareeae, Coussarea, Faramea, Guianas, South America, floristics, taxonomy.

\section{INTRODUCTION}

Coussarea, of about 110 species, and Faramea, of about 130 species, are sister genera in the tribe Coussareeae (sensu Andersson \& Rova, 1999, f. 3). A third genus, Schizocolea Bremek., endemic to tropical Africa, was suggested to belong to this tribe (Bremekamp, 1951; Petit, 1962; Robbrecht, 1988). It differs from the other two by its stipules basally long-tubular and distally fimbriate; its systematic position remains uncertain. In addition, the generic boundary between Coussarea and Faramea is not well defined, since it is mostly based on stipule shape (triangular or rounded in Coussarea vs commonly aristate or rarely triangular in Faramea), fruit morphology (1-seeded, by abortion of one ovule, in Coussarea vs 1- or 2-seeded in Faramea), and corolla colour (white in Coussarea vs blue or white in Faramea) which are all characters that intergrade. The geographic distributions of Coussarea and Faramea are also similar, since both genera are restricted to the Neotropics, and their main centres of diversity are the Andean cloud forests, the Brazilian Atlantic forests, and the Guayana Shield. The two taxa might, therefore, even be congeneric. However, for the moment the two genera are defined according to the traditional delimitations adopted by Bremekamp (1934a, b), Steyermark (1967, 1974), Boom \& Delprete (2002), and Taylor \& Steyermark (2004).

1) Current address: Federal University of Goiás, Campus II, Institute of Biological Sciences - ICB-1, Department of General Biology/Botany, 74001-970 Goiânia, Goiás, Brazil;

e-mail: pdelprete@hotmail.com 


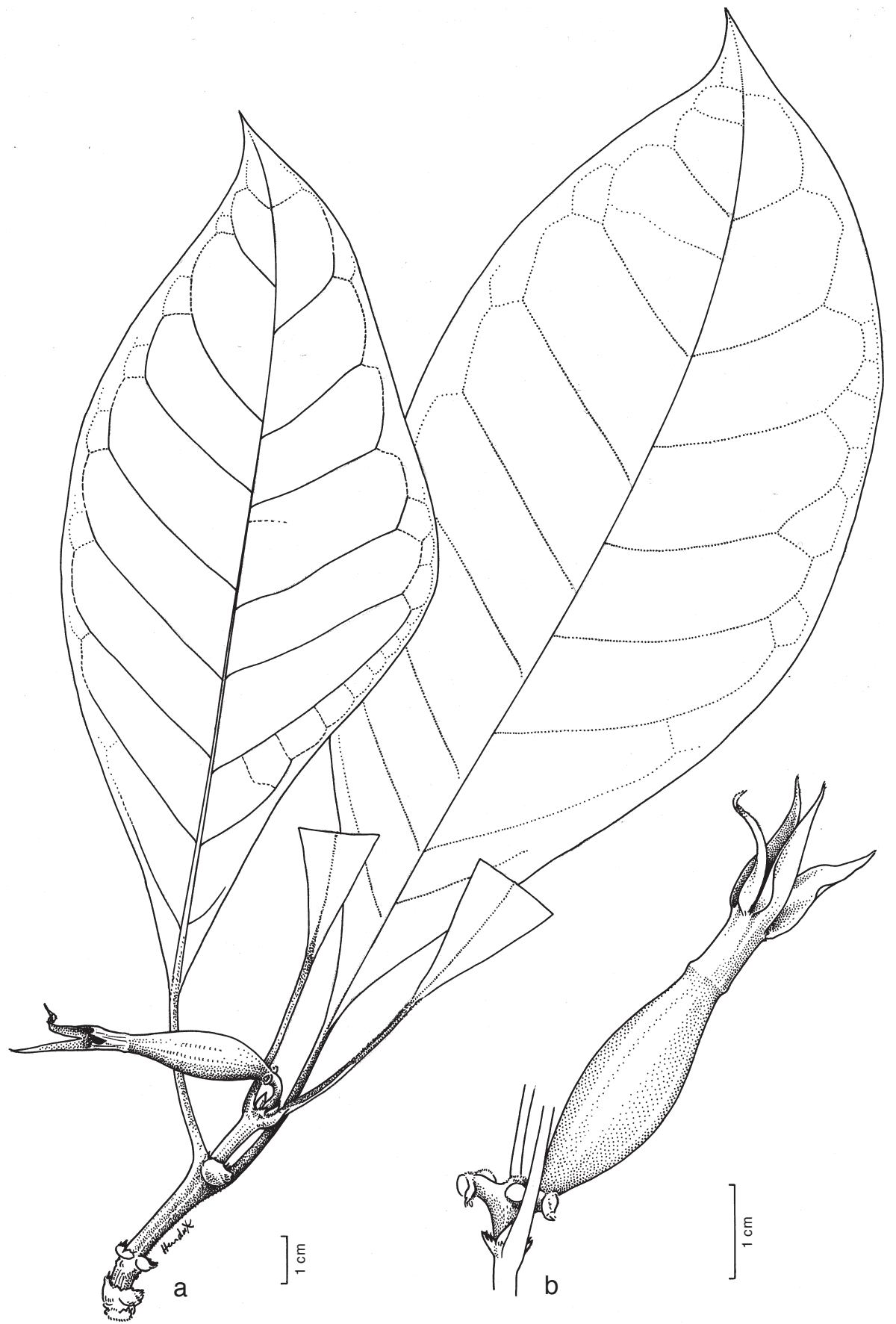

Fig. 1. Coussarea longilaciniata Delprete. a. Habit of terminal branchlet with mature fruit; $b$. detail of peduncle and mature fruit (all: Hahn et al. 5643). 
A revision of the species of Coussarea and Faramea occurring in the Guayana Highlands and contiguous areas was published by Steyermark (1967), where he recognized 20 species of Coussarea and 30 of Faramea. More recently, the species of Coussarea and Faramea from central French Guiana (Saül) have been studied by Boom \& Delprete (2002), who also described a new species of Coussarea from that area (Delprete $\&$ Boom, 1999). In addition, a treatment of the species of these two genera occurring in the Venezuelan Guayana was recently published by Taylor \& Steyermark (2004), facilitating the present study.

\section{SYSTEMATIC TREATMENT}

\section{COUSSAREA}

During the preparation of the treatment of the Rubiaceae for the Flora of the Guianas (Delprete, in prep.), two new species of Coussarea have been detected, although only known from fruiting specimens. Because of their unique features, it is evident that these are distinct species that need to be described, in order to have their names available for the Flora of the Guianas treatment. The first species is unique in Coussarea by its long, lanceolate calyx lobes (16-18 mm long), and is described below as $C$. longilaciniata Delprete; the second species is unique in the genus by its interrupted-spicate inflorescences, and is described below as $C$. spicata Delprete. Including these two new taxa, about 13 species of Coussarea are known to occur in the Guianas.

\section{Coussarea longilaciniata Delprete, spec. nov. - Fig. 1}

Praecipue calyce magna Coussareae macrocalyx similis, sed differt stipulis persistentibus (nec caducis), inflorescentia reducta 3-7-flora (vs paniculata multiflora in C. macrocalyx) atque lobis calycis longe lanceolatis $16-18 \mathrm{~mm}$ longis (nec triangularibus vel anguste triangularibus 1.5-5 mm longis). - Typus: Hahn, Gillespie \& Persaud 5643 (holo NY; iso US), Guyana, Reg. Potaro-Siparuni, ca. 1-3 km SW of Paramakotoi, $650 \mathrm{~m}, 4^{\circ} 42^{\prime} \mathrm{N}$, $59^{\circ} 48^{\prime} \mathrm{W}, 13$ March 1989.

Trees 6-10 m tall; leafy branchlets laterally compressed, sparsely to densely shortpubescent. Stipules free at base, broadly triangular, round or truncate at apex, appressed pubescent outside, $2.5-3 \mathrm{~mm}$ long, $2.5-5 \mathrm{~mm}$ wide at base, persistent, sometimes breaking off at older nodes. Petioles $23-52 \mathrm{~mm}$ long, appressed pubescent; blades obovate, elliptic to oblong-elliptic, $17.5-23.5$ by $5.5-10 \mathrm{~cm}$, acute at base, obtuse to acuminate at apex, acumen 1-1.5 cm long, dark green above, pale green below, drying olive-green, papyraceous, glabrous above, sparsely pubescent below; secondary veins appressed or spreading pubescent below, 7-9 on each side; domatia small tufts of hairs at the axils of the secondary veins. Inflorescences sessile or short-pedunculate, extremely reduced corymbs, 3-7-flowered, with 1 or 2 branches $9-13 \mathrm{~mm}$ long, pubescent, peduncle to $6 \mathrm{~mm}$ long. Flowers unknown. Immature fruits sessile, ellipsoid, $25-33$ by $13-15 \mathrm{~mm}$, appressed-pubescent, white or yellow, with persistent calyx 24-26 mm long, appressed-pubescent, tube 8-9 mm long, lobes narrowly lanceolate, 16-18 $\mathrm{mm}$ long, $2.5-5 \mathrm{~mm}$ wide at base, sparsely pubescent.

Distribution - Guyana, only known from 2 collections. 
Ecology - Disturbed forests at $90 \mathrm{~m}$ altitude, and tall wet forests at $650 \mathrm{~m}$ altitude, on red lateritic soil.

Phenology - The two fruiting collections were made in March and April.

Notes - Because of the large calyx, C. longilaciniata is most similar to C. macrocalyx Standl., which is restricted to western Colombia and western Ecuador (cf. Taylor, 1999: 262), from which it differs by having persistent stipules (vs caducous in C. macrocalyx), inflorescence 3-7-flowered, comprised of 1 or 2 short branches (vs many-flowered, paniculate, with 2 or 3 pairs of secondary branches in C. macrocalyx), and calyx lobes long-lanceolate, $16-18 \mathrm{~mm}$ long (vs calyx lobes triangular to narrowly triangular, 1.5-5 mm long in C. macrocalyx).

The type specimen of $C$. longilaciniata has previously been identified as C. leptoloba (Spreng. ex Hook.f.) Müll.Arg., but this species has a calyx tube of 5-6 mm long (vs 8-9 mm long in C. longilaciniata), calyx lobes $2-3 \mathrm{~mm}$ long (vs $16-18 \mathrm{~mm}$ long in C. longilaciniata), and fruits c. 18 by $12 \mathrm{~mm}$ (vs immature fruits $25-33$ by $13-15 \mathrm{~mm}$ in C. longilaciniata).

Because of the large fruits, C. longilaciniata is also similar to C. megalocarpa Standl., a species found only in the Peruvian Amazon (cf. Standley, 1931), but this species differs by having caducous stipules (vs persistent in C. longilaciniata), leaf blades with 11-13 secondary veins each side (vs 7-9 each side in $C$. longilaciniata), many-flowered inflorescences (vs 3-7-flowered in C. longilaciniata), and linear calyx lobes to $12 \mathrm{~mm}$ long (vs narrowly lanceolate, $16-18 \mathrm{~mm}$ long in $C$. longilaciniata).

Additional specimens studied:

GuYANA. Hahn et al. 5643 (holo NY; iso US), Reg. Potaro-Siparuni, c. 1-3 km SW of Paramakotoi, $650 \mathrm{~m}, 4^{\circ} 42^{\prime} \mathrm{N}, 59^{\circ} 48^{\prime} \mathrm{W}$; McDowell et al. 4269 (NY, US), Reg. Barima-Waini, site of old mining operation Old World, $7^{\circ} 22^{\prime} \mathrm{N}, 60^{\circ} 28^{\prime} \mathrm{W}, 91 \mathrm{~m}$.

McDowell et al. 4269 have immature fruits, with the calyx lobes broken off (c. $2.2 \mathrm{~mm}$ wide at base); however, because of the $8-9 \mathrm{~mm}$ long calyx tube, these specimens are tentatively identified as belonging to this species.

\section{Coussarea spicata Delprete, spec. nov. - Fig. 2}

Praecipue Coussareae spiciformi similis sed differt stipulis persistentibus (nec caducis), laminis nervis secundariis utrinque 15-17 (nec 11-12), inflorescentiis interrupte spiciformibus $12-13 \mathrm{~cm}$ longis (versus paniculate spiciformibus $3.5-4.5 \mathrm{~cm}$ longis in $C$. spiciformi). - Typus: Granville, Cremers, Hagemann, Leuenberger \& Sangrey 10779 (holo NY; iso CAY), French Guiana, Reg. de l'Inini, Mt Atachi Bacca, S of plateau, 12 km SE of Gobaya Soula, $780 \mathrm{~m}, 3^{\circ} 33^{\prime} \mathrm{N}, 53^{\circ} 55^{\prime} \mathrm{W}, 19$ January 1989.

Small tree $4 \mathrm{~m}$ tall; leafy branchlets laterally compressed, sparsely spreading pubescent. Stipules connate at base, broadly triangular, round or truncate at apex, sparsely pubescent outside, 2.5-3 mm long, 2.5-5 mm wide at base, persistent, often partially breaking off at older nodes. Petioles 17-20 mm long, sparsely spreading pubescent; blades narrowly obovate to oblong-elliptic, $25-28.5$ by $8-10.5 \mathrm{~cm}$, acute to decurrent at base, acuminate at apex, acumen $2-2.5 \mathrm{~cm}$ long, dark green above, pale green below, drying olive-green, papyraceous, glabrous above, sparsely pubescent below; secondary veins sparsely puberulent above, sparsely spreading pubescent below, 15-17 on each side; domatia absent. Inflorescence a pedunculate, interrupted spike-like panicle, 


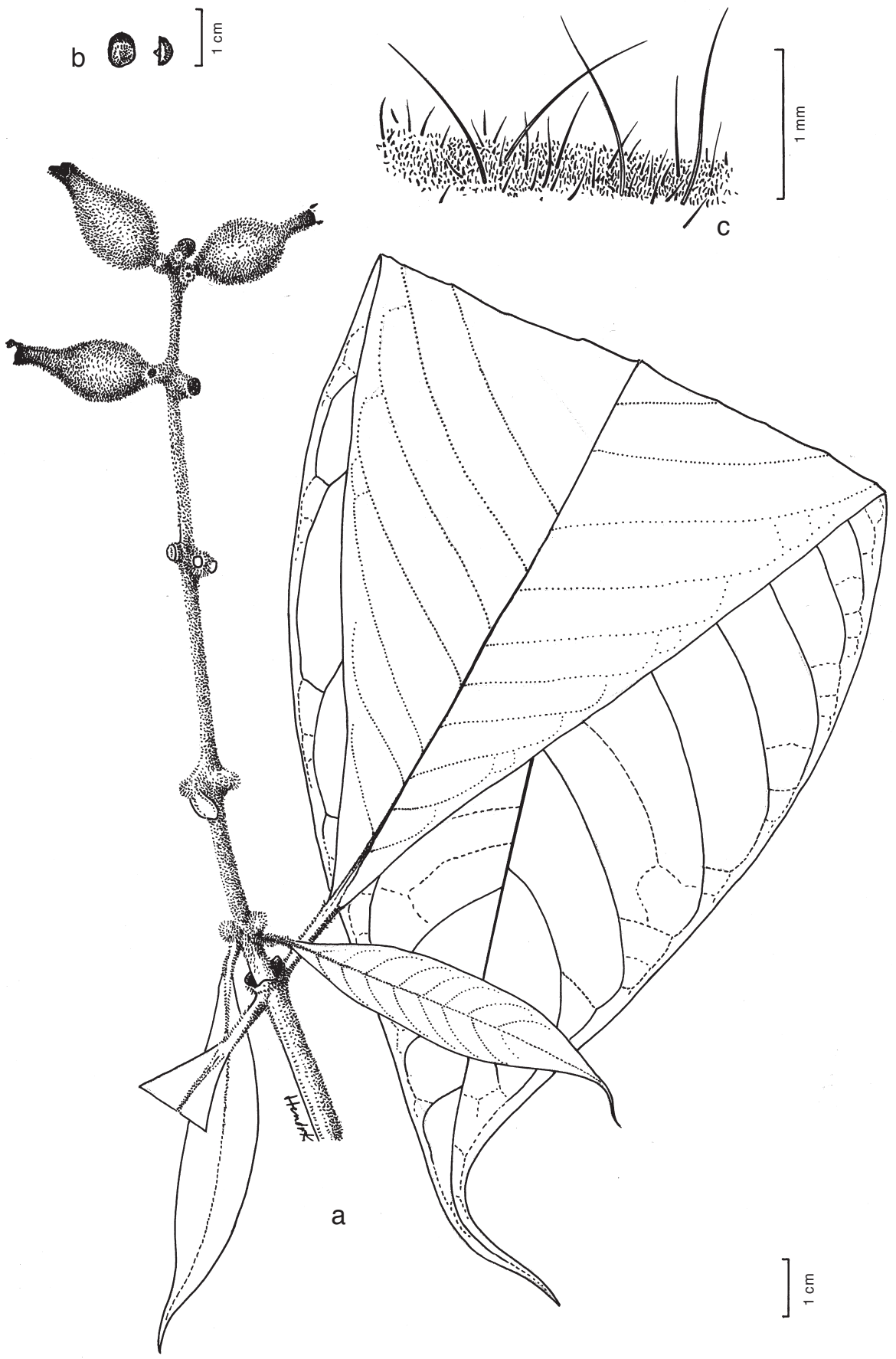

Fig. 2. Coussarea spicata Delprete. a. Habit of terminal branchlet with infructescence; b. seed, ventral and lateral view; c. detail of fruit vestiture (all: Granville et al. 10779). 
12-13 cm long, densely pubescent, with pairs of flower fascicles at regular intervals decreasing towards the apex (basal ones 38-40 mm long, medial 32-34 mm, distal 18-20 mm), fascicles 1-3(-4)-flowered, peduncle $30 \mathrm{~mm}$ long. Flowers unknown; the specimen label reports "corolla tube pale green, $2 \mathrm{~cm}$ long, lobes 4 , lanceolate, white, $2 \mathrm{~cm}$ long". Immature fruits ellipsoid, sessile, $17-20$ by $13-15 \mathrm{~mm}$, with two types of hairs, the surface covered by densely golden-puberulent and intermixed sparsely erect-pubescent hairs $(0.3-1.3 \mathrm{~mm}$ long), pale yellow, with persistent calyx, sparsely erect-pubescent, tube 5.5-7 mm long, lobes unknown (broken off in fruits).

Distribution - French Guiana, only known from the type collection.

Ecology - Submontane forest, on the plateau of the Atachi Bacca Mt, at $780 \mathrm{~m}$ altitude.

Notes - Because of the spiciform inflorescences C. spicata is similar to C. spiciformis C.M. Taylor, recently described from Amazonian Ecuador (cf. Taylor, 1999: 270-271); however, the former is distinguishable from the latter by its persistent stipules (vs caducous in $C$. spiciformis), leaf blades with 15-17 secondary veins each side (vs 11-12 each side in C. spiciformis), and interrupted spike-like inflorescences $12-13 \mathrm{~cm}$ long (vs paniculate-spiciform, $3.5-4.5 \mathrm{~cm}$ long in C. spiciformis).

The type specimen of $C$ spicata has previously been identified as C. leptoloba; however, the latter can be distinguished from the former by the leaf blades with 11 or 12 secondary veins each side (vs 15-17 each side in $C$. spicata), inflorescences trichotomous, $1.3-2.5 \mathrm{~cm}$ long (vs interrupted-spiciform, $12-13 \mathrm{~cm}$ long in C. spicata), and fruits uniformly pubescent (vs with two types of hairs, densely golden-puberulent and sparsely erect-pubescent, in C. spicata).

\section{FARAMEA}

Bremekamp (1957) and Steyermark (1967) distinguished Faramea sessiliflora var. pedunculata Bremek. from the typical variety because of the "peduncles 1-2.5 cm long" (vs "peduncles absent" in var. sessiliflora). Steyermark had some doubts about maintaining the two varieties separate, because the respective types were both collected at the same locality (Kaw Mts, French Guiana) and the scanty specimens available. Recent collections from wider geographic ranges showed that many additional characters are present to distinguish the two taxa, and var. pedunculata is here raised to species level. Faramea pedunculata (Bremek.) Delprete is easily distinguished from F. sessiliflora Aubl. because of the pale orange, $20-28$ by $7-17 \mathrm{~mm}$, readily caducous bracts (vs green, $12-15$ by $5-7$ $\mathrm{mm}$, persistent bracts in $F$. sessiliflora), calyx with 4 linear lobes (vs truncate or undulate in F. sessiliflora), corollas $29.5-35.5 \mathrm{~mm}$ long (vs 17-22 mm long in F. sessiliflora), anthers 2.8-3 mm long (vs 4.5-5 mm long in F. sessiliflora), style 15-16.5 mm long (vs 10-11 $\mathrm{mm}$ long in F. sessiliflora), and fruits ebracteate, globose to subglobose, 13-17 by 11-13 $\mathrm{mm}$ (vs fruits subtended by permanent bracts, transversally oblong-ellipsoid, 3.5-5 by $8.5-11 \mathrm{~mm}$ ). In addition, because of the change of status of var. pedunculata, it is necessary to provide a new description of $F$. sessiliflora in order to re-delimit this species.

With the new rearrangements here proposed and as a result of the ongoing studies, about 22 species of Faramea are known to occur in the Guianas. 


\section{Faramea pedunculata (Bremek.) Delprete, comb. \& stat. nov.}

Faramea sessiliflora Aubl. var. pedunculata Bremek. (1957) 241. - Type: Cowan 38808 (holo NY; iso U), French Guiana, Kaw Mt, 250-270 m.

Trees 4-8 m tall, to $15 \mathrm{~cm}$ dbh; leafy branchlets laterally compressed, glabrous. Stipules free at base, aristate, 5-7 mm long, glabrous, readily caducous, base narrowly triangular, $1.5-2.5$ by $1.5-2 \mathrm{~mm}$, arista $3.5-4.5 \mathrm{~mm}$ long. Leaves petiolate; petioles 5-12 mm long, glabrous; blades elliptic to oblong-elliptic, $7.5-13.5$ by $2.4-5.5 \mathrm{~cm}$, obtuse to acute at base, round, obtuse to acuminate at apex, acumen narrowly triangular to linear, $0.8-1.5 \mathrm{~cm}$ long, dark green above, pale green below, drying olive-green to whitish-pale green, chartaceous to papyraceous, glabrous throughout; secondary veins 8-12 each side, yellow below; domatia absent. Inflorescences terminal, sessile, with 3 axes, the 2 lateral ones 5-18 $\mathrm{mm}$ long, the middle one 9-25 mm long, pale brown, each axis terminating with 3 flowers subtended by 2 outer bracts; bracts ovate, 20-28 by 7-17 $\mathrm{mm}$, round to obtuse at base, acute at apex, membranaceous, pale orange (fide Granville et al. 10828), falling off shortly after anthesis. Flowers sessile or subsessile (the 2 lateral ones sessile, the middle one with pedicel to $2 \mathrm{~mm}$ long), hypanthium obovoid, c. 1.5 mm long, glabrous; calyx cupular, 1-1.5 mm long, truncate, undulate or minutely denticulate, glabrous; corolla 29.5-35.5 mm long, glabrous, white, tube 20-25 mm long, narrowly cylindrical, $1.5-2.3 \mathrm{~mm}$ wide, lobes linear-lanceolate, $9.5-10.5$ by $1.5-2.5$ $\mathrm{mm}$, acuminate at apex, glabrous, stamens included, inserted at 3.5-4 $\mathrm{mm}$ from the base of the tube, anthers sessile, narrowly oblong, $2.8-3$ by $0.3-0.4 \mathrm{~mm}$, acute at apex; style included, 15-16.5 mm long, glabrous, style branches linear, 2.8-3.3 mm long. Fruits globose to subglobose, usually only 1 or 2 per each axis, smooth, 13-17 by 11-13 mm (immature, green fruits $9-11 \mathrm{~mm}$ in diam. in Mori \& Pipoly 15474), passing from green to yellow to red in different stages of maturation, and turning dark purple at complete maturity, drying pale brown when immature, and bluish-black when mature (Feuillet et al. 10181).

Distribution - Guyana and French Guiana.

Ecology - Tree growing in xeromorphic or open forests on mountain summits, on lateritic soils, at 200-780 m altitude.

Phenology - Flowering specimens were collected in December and January; fruiting specimens were collected in April, June, September and October.

Note - Because of the umbellate inflorescences $F$. pedunculata could be confused with F. parvibractea Steyerm. and F. berryi Steyerm. Faramea parvibractea is a widespread species ranging from Central America to the Amazon Basin, that can be easily distinguished from $F$. pedunculata by its inflorescences with 7-19 axes (vs 3 axes in F. pedunculata) and corolla tube 6-7.5 mm long and lobes 6-9.5 mm long (vs tube 20-25 $\mathrm{mm}$ long and lobes $9.5-10.5 \mathrm{~mm}$ long in F. pedunculata). Faramea berryi occurs in Colombian, Venezuelan and Brazilian Amazon, and differs from $F$. pedunculata by its inflorescences with 7-9 axes, corollas 5-5.5 mm long, and oblate fruits c. 4 by $6 \mathrm{~mm}$ (vs globose to subglobose, $13-17$ by $11-13 \mathrm{~mm}$ ).

Additional specimens examined:

French Guiana. Cowan 38808 (holo NY; iso U), Kaw Mt, 250-270 m; Feuillet et al. 10181 (CAY, NY), Régina, E plateau of Mt Tortue, $11 \mathrm{~km} \mathrm{WNW} \mathrm{of} \mathrm{Appropague} \mathrm{R.,} \mathrm{near} \mathrm{source} \mathrm{of} \mathrm{Cr.}$ Feuillet, $4^{\circ} 28^{\prime}$ N, 52 $22^{\prime}$ W, 200-450 m; Mori \& Pipoly 15474 (CAY, NY, U), Saül, Antenne Nord 
de La Fumée, 200-400 m; Mori et al. 14928 (CAY, NY, U), Saül, Mts La Fumée, $3^{\circ} 37$ N, 53 12' W, 200-400 m; Granville et al. 10828 (CAY, NY, U), Reg. Inini, Mt Atachi Bacca, summit of central plateaux, near Camp IV, $780 \mathrm{~m}, 3^{\circ} 33^{\prime} \mathrm{N}, 53^{\circ} 55^{\prime} \mathrm{W}$.

SURINAME. Lindeman et al. 257 (NY, U), Lely Mts, SW Plateau, 550-710 m, S border of plateau 5, in line 1339 opened by bulldozer; Mori \& Bolten 8558 (NY, U), Lely Mts, 175 km SSE of Paramaribo, 500-700 m, between plateaus 1 and 2 .

\section{Faramea sessiliflora Aubl.}

Faramea sessiliflora Aubl. (1775) 104, t. 40, f. 2, as 'sessiflora'. - Type: Aublet s.n. (holo BM), French Guiana, 'sylvis Caux' [now Kaw].

Shrub or treelet 1.5-2 m tall; leafy branchlets slender, scandent, laterally compressed, glabrous. Stipules free at base, long-aristate, $5-7 \mathrm{~mm}$ long, glabrous, readily caducous, base broadly triangular to deltoid, $1-2$ by $1.5-2 \mathrm{~mm}$, arista setaceous, $4-5.5 \mathrm{~mm}$ long. Leaves short-petiolate; petioles $2-5 \mathrm{~mm}$ long, glabrous; blades elliptic to oblongelliptic, narrowly-elliptic to narrowly lanceolate, $4.5-14.5$ by $2.5-5 \mathrm{~cm}$, obtuse to acute at base, obtuse to acuminate at apex, acumen narrowly triangular to linear, $0.8-2.5 \mathrm{~cm}$ long, dark green above, pale green below, drying olive-green, chartaceous, glabrous throughout; secondary veins 7-11 each side, yellow below; domatia absent. Inflorescences terminal, sessile, with 3 short axes, the 2 lateral ones $1-3 \mathrm{~mm}$ long, the middle one $2-3.5 \mathrm{~mm}$ long, yellowish-green, each axis terminating with 1 or 2 (or 3) flowers subtended by 2 outer bracts; bracts narrowly ovate, $12-15$ by $5-7 \mathrm{~mm}$, round to obtuse at base, acute at apex, membranaceous, green (fide Oldeman 3073), permanent. Flowers sessile, hypanthium obovoid, c. $1 \mathrm{~mm}$ long, glabrous; calyx cupular, 1-1.5 mm long, with 4 linear lobes 1-2 mm long, glabrous; corolla 17-22 mm long, glabrous, white, tube 12-14 mm long, narrowly cylindrical, c. $1.3 \mathrm{~mm}$ wide, lobes linear-lanceolate, $5-8.5$ by $1.2-1.5 \mathrm{~mm}$, acuminate at apex, glabrous, stamens mostly included (only anther tips exserted), inserted above the middle of the corolla tube, anthers sessile, narrowly oblong, $4.5-5$ by $0.3 \mathrm{~mm}$, acute at apex; style included, $10-11 \mathrm{~mm}$ long, glabrous, style branches linear, $1.3-1.5 \mathrm{~mm}$ long. Fruits transversally oblong-ellipsoid, 1 per each inflorescence, subtended by the permanent green bracts, smooth, $3.5-5$ by $8.5-11$ $\mathrm{mm}$, green at complete maturity, drying pale green.

Distribution - Widespread through the Amazon Basin, in Suriname, French Guiana, and in the Brazilian states of Amazonas, Mato Grosso and Pará.

Ecology - Undercanopy shrub or treelet, in gallery forests, at $80-150 \mathrm{~m}$ altitude.

Phenology - Flowering from September through December, and fruiting from April through August.

Notes - Faramea sessiliflora was described and illustrated in Aublet's (1775) 'Histoire des plantes de la Guiane Françoise'; while in the text (p. 104) the name of this species was spelled "FARAMEA (sessiflora)", in the figure legend (t. 40, f. 2) the specific epithet was written "sessiliflora". The name of the figure legend was adopted by all subsequent authors, and is therefore here maintained. Aublet's text provides a detailed description of the taxon, and the rather simple figure shows the terminal inflorescence with three subsessile axes, each one with a pair of bracts enclosing the flowers, as it can be confirmed by the type specimen preserved at BM, and therefore clarifying the identity of this species. 
Faramea sessiliflora is unique within the genus by its terminal, sessile inflorescences, with 3 short axes 1-3.5 mm long, each with two green, persistent bracts that subtend the fruits at full maturity.

Additional specimens studied:

BRAZIL. Amapá: Irwin et al. 47611 (NY, U), Oiapoque R., opposite Pedra Alice, $3^{\circ} 40^{\prime} \mathrm{N}$, $52^{\circ} 01^{\prime}$ W. Amazonas: Krukoff 6781 (NY, U [2]), Mun. Humaitá, near Livramento, on R. Livramento. Mato Grosso: Prance et al. 19102 (NY, U [2]), Chapada dos Guimarães, Gorge of Veu da Noiva.

French GuiANA. Aublet s.n. (holo BM), 'sylvis Caux' [now Kaw]; Granville B-4927 (CAY, NY, U), Ouaqui R., Saut Macaque; Granville 1766 (CAY, U), Ouaqui R., L side, between Saut Macaque and Saut Stouman Fou l'Inspecteur; Oldeman T-852 (CAY, NY, U), Oyapock R., chemin Maripa, layon ORSTOM du km 1 au km 2; Oldeman 3073 (CAY, NY, U), pied du Saut Oaimicouaré, Ya Roupi R. (affluent of Oyapock R.); Oldeman T-499 (CAY, NY), Yaroupi R., Saut Tsinoua; Oldeman B-3103 (CAY, U), Yaroupi R., L side, Saut Coueki; Oldeman B-3179 (CAY, U), U. Oyapock R., abandoned indigenous village near Saut Coyari.

SURINAME. Lindeman 5028 (U, Uw 3416), Jodensavanne-Mapane Cr. (Suriname R.), near camp 12, block 836; Lindeman 4667 (U), Jodensavanne-Mapane Cr. (Suriname R.), slight slope N of Mapane Cr., base III, block 836; Florschütz \& Maas 2417 (U), Bakhuis Mts, between Kabalebo R. and Coppename R., track from Kabalebo airstrip to 1-2 km S, 80-150 m.

\section{ACKNOWLEDGEMENTS}

Funds for this work were provided by a fellowship from the Netherlands Organization for Scientific Research NWO (grant B 85-368) for the treatment of the Rubiaceae for the Flora of the Guianas. My profound gratitude goes to Marion Jansen-Jacobs (U) for the efficient coordination of the project, Paul Maas for the general supervision, and the entire staff of the Nationaal Herbarium Nederland, Utrecht University branch (U), for the friendly collaboration and the pleasant professional environment. This project was realized also through major loans (c. 3,000 specimens) from NY and US to U, for which the generous support of these institutions is here acknowledged. During 1999 I visited the herbarium at Cayenne (CAY), French Guiana, where I studied and annotated about 5,000 Rubiaceae specimens from the Guianas, which much advanced the present study, and I wish to thank the staff of this institution for the valuable collaboration and working space. I am particularly grateful to Hendrik Rypkema $(U)$ for the beautiful line drawings, Lubbert Westra $(U)$ for the Latin descriptions and for the proof-reading of the preliminary version of the manuscript. The final revision of this paper was made during a fellowship for Visiting Scientist from the National Council for Scientific and Technological Development (Conselho Nacional de Desenvolvimento Cientifico e Tecnologico - CNPq) of the Brazilian Government (grant 309885/2003-5), at the Federal University of Goiás, Goiânia, Goiás, Brazil.

\section{REFERENCES}

Andersson, L. \& J.H.E. Rova. 1999. The rps16 intron and the phylogeny of the Rubioideae (Rubiaceae). Pl. Syst. Evol. 214: 161-186.

Aublet, J.B.C.F. 1775. Faramea sessiliflora. Histoire des plantes de la Guiane Françoise 1: 104-105, pl. 40, f. 2. Didot Jeune, Paris.

Boom, B.M. \& P.G. Delprete. 2002. Rubiaceae. In: S. A. Mori, G. Cremers, C. A. Gracie, J.J. de Granville, S.V. Head, M. Hoff \& J.D. Mitchell (eds.), Guide to the vascular plants of central French Guiana. Part 2. Dicotyledons. Mem. New York Bot. Gard. 76, 2: 606-649.

Bremekamp, C.E.B. 1934a. Rubiaceae. In: A.A. Pulle (ed.), Flora of Suriname 4: 113-298. De Bussy Ltd., Amsterdam.

Bremekamp, C.E.B. 1934b. Notes on the Rubiaceae of Surinam. Recueil Trav. Bot. Néerl. 31: 248-308. [reimpr. Meded. Bot. Mus. Herb. Rijks Univ. Utrecht 11: 248-308]. 
Bremekamp, C.E.B. 1951. Schizocolea linderi (Hutch. et Dalz.) Brem. Hooker's Icon. Pl. 35: ad t. 3482.

Bremekamp, C.E.B. 1957. Rubiaceae. In: R.S. Cowan et al. (eds.), New species and records of plants in Guiana. Brittonia 8: 241-245.

Delprete, P.G. In prep. Rubiaceae, Part I. Introduction, Key to Genera, and Genera from A to L. In: M.J. Jansen-Jacobs (ed.), Flora of the Guianas. Royal Botanic Gardens, Kew, Richmond, Surrey, United Kingdom.

Delprete, P.G. \& B.M. Boom. 1999. Coussarea granvillei (Rubiaceae, Coussareeae), a new species from French Guiana. Brittonia 51: 403-406.

Petit, E. 1962. Rubiaceae africanae IX. Notes sur les genres Aidia, Atractogyne, Aulacocalyx, Batopedina, Gaertnera, Morinda, Mussaenda, Nauclea, Sabicea, Schizocolea et Tricalysia. Bull. Jard. Bot. État 32: 173-198.

Robbrecht, E. 1988. Tropical woody Rubiaceae. Characteristic features and progressions. Contributions to a new subfamilial classification. Opera Bot. Belg. 1: 1-271.

Standley, P.C. 1931. Coussarea megalocarpa. Studies on American plants - V. Publ. Field Columbian Mus., Bot. Ser. 8: 366-367.

Steyermark, J.A. 1967. Coussarea, Faramea. In: B. Maguire et al. (eds.), Botany of the Guayana Highlands, Part VII. Mem. New York Bot. Gard. 17, 1: 360-396.

Steyermark, J.A. 1974. Coussareae (Rubiaceae). In: T. Lasser \& J.A. Steyermark (eds.), Flora de Venezuela 9: 13, 27-28, 918-967. Instituto Botánico, Caracas.

Taylor, C.M. 1999. Rubiaceae-Coussareeae. In: G. Harling \& L. Andersson (eds.), Flora of Ecuador 62: 245-314. Council for Nordic Publications in Botany, Copenhagen, Denmark.

Taylor, C.M. \& J. A. Steyermark. 2004. Coussarea, Faramea. In: J.A. Steyermark, P.E. Berry \& B.K. Holst (eds.), Flora of the Venezuelan Guayana 8: 562-567, 589-599. Missouri Botanical Garden Press, St. Louis, MO, USA. 